\title{
Ranking Turkish Cities and Regions for Air Quality Using a Multi-Criteria Decision-Making Method
}

\author{
Emin Sertaç Arı ${ }^{1 *}$, Hakan Özköse ${ }^{1}$, Cevriye Gencer ${ }^{2}$ \\ ${ }^{1}$ Institute of Informatics, Gazi University, \\ Tunus cad. No. 35, Kavaklıdere, Ankara, Turkey \\ ${ }^{2}$ Department of Industrial Engineering, Faculty of Engineering, \\ Gazi University, 06570, Maltepe, Ankara, Turkey
}

Received: 19 March 2016

Accepted: 14 May 2016

\begin{abstract}
Every year environmental authorities in every country publish quality reports on natural elements such as air, water, and soil. Such reports provide insight about these essential elements for the directors of the related regions and give them a chance to take measures when it possesses risk. Air quality varies according to the quantities of the materials in it. Especially during the winter, air pollution is relatively high in some regions depending on meteorological conditions. Numerous pollutants exist in the air, such as particulate matter, sulfur dioxide, nitrogen oxides, carbon monoxide, and ozone. In this study, based on the amounts of the pollutants as criteria, at the first stage 81 cities and at the second stage seven regions of Turkey are ranked according to air quality. The status of the cities and the regions in terms of air quality can be seen with this ranking, which is done using stochastic multi-criteria acceptability analysis (SMAA-2) - a stochastic multicriteria decision-making method.
\end{abstract}

Keywords: air pollution, air quality, multi-criteria decision making, SMAA-2, ranking

\section{Introduction}

The urban argument currently assumes an extreme level of relevance for governments and society in general, due to the exponential increase of people living in cities. This often enhances stresses on space, ecosystems, infrastructures, facilities, and lifestyles. Nevertheless, the uncontrolled growth of cities might lead to a decrease in quality of the urban environment [1].
According to Conserve Energy Future, pollution is the world's most pressing environmental problem [2]. Countries try to take immediate measures against all kinds of pollution within their scopes. Similarly, air pollution is a major problem that has been recognized throughout the world for hundreds of years [3]. Civil and state authorities for the environment make continuous observations and produce periodic reports that give detailed information to those concerned. Almost all of them give the amounts or percentages of the pollutants and determine the most polluted places based on each pollutant threshold.

Several studies have been carried out that present various techniques to rank air quality results. For example, 
Silva performed a study in Portugal that presents an urban environmental quality health index based on noise levels and air pollutant concentrations [1]. Dobrot et al. used a novel statistical approach, the I-distance method, to examine air pollution in European Union member countries [4]. The issue was measuring the air pollution of each country in terms of six criteria and ranking them. A study by Sheng and Tang provided a review and analysis of air pollution in China from city to regional scales based on monthly reports. The official air quality rankings of the 74 cities were discussed from the aspects of geographical location, economic development mode, and regional air quality management [5].

This study develops an integrated point of view of the ranking process by taking all of the pollutants into consideration and combining them in one analysis. It is a novel study when considered from this point of view.

\section{Air Pollutants}

Air pollution is one of those kinds of pollution and authorities claim that it causes several health problems - from respiratory and heart problems to cancer. Other effects of air pollution can be counted as global warming, acid rain, depletion of the ozone layer, extinction of wildlife, etc. [2]. The most important causes of air pollution are reported to be fossil fuels, exhaust from factories and industries, mining operations, and some agricultural activities [2].

Seven main air pollutants have been accepted by all environmental authorities in the world: particulate matter $(\mathrm{PM})$, sulfur dioxide $\left(\mathrm{SO}_{2}\right)$, nitrogen oxides $\left(\mathrm{NO}_{\mathrm{x}}\right.$, including nitrogen monoxide (NO) and nitrogen dioxide $\left(\mathrm{NO}_{2}\right)$ ), carbon monoxide $(\mathrm{CO})$ and ozone $\left(\mathrm{O}_{3}\right)$. The European Environment Agency explains those pollutants, their causes, and effects as follows [6]:

- PM is a mixture of aerosol particles (solid and liquid) covering a wide range of sizes and chemical compositions. $\mathrm{PM}_{10}\left(\mathrm{PM}_{2.5}\right)$ refers to particles with a diameter of 10 (2.5) micrometers or less. PM is either directly emitted as primary particles or it forms in the atmosphere from emissions of $\mathrm{SO}_{2}, \mathrm{NO}_{\mathrm{x}}$, $\mathrm{NH}_{3}$, and Non-methane volatile organic compounds (NMVOC). Important natural sources of PM are sea salt and natural re-suspended dust. PM can cause or aggravate cardiovascular and lung diseases, heart attacks, and arrhythmias. It can also affect the central nervous system and the reproductive system, and can cause cancer. One outcome of exposure to PM can be premature death. PM also acts as a greenhouse gas, mainly cooling the earth's climate, although in some cases it can lead to warming. PM in the atmosphere can also alter rainfall patterns, and affect the surface albedo properties of snow (the extent to which the snow reflects light).

- $\mathrm{SO}_{2}$ is formed by oxidation of Sulphur (S), mainly through combustion of fuels containing $\mathrm{S}$. The electricity generation sector is the most important source of $\mathrm{SO}_{2}$. $\mathrm{SO}_{2}$ also can contribute to the formation of secondary sulphate particles in the atmosphere. $\mathrm{SO}_{2}$ aggravates asthma and can reduce lung function and inflame the respiratory tract. It can cause headache, general discomfort, and anxiety. $\mathrm{SO}_{2}$ contributes to acid deposition, the impacts of which can be significant, causing damage to forests and ecosystems in rivers and lakes.

- $\mathrm{NO}_{\mathrm{x}}$ is emitted during fuel combustion, e.g., from industrial facilities and the road transport sector. $\mathrm{NO}_{\mathrm{X}}$ is a group of gases comprising nitrogen monoxide (NO) and nitrogen dioxide $\left(\mathrm{NO}_{2}\right)$. $\mathrm{NO}$ makes up the majority of $\mathrm{NO}_{\mathrm{X}}$ emissions. $\mathrm{NO}_{\mathrm{X}}$ contributes to the formation of ozone and particulate matter. $\mathrm{NO}_{2}$ is associated with adverse effects on health: it can affect the liver, lung, spleen, and blood. It can also aggravate lung diseases leading to respiratory symptoms and increased susceptibility to respiratory infection. As with $\mathrm{SO}_{2}, \mathrm{NO}_{\mathrm{X}}$ contributes to acid deposition but also to eutrophication of soil and water.

- $\mathrm{CO}$ is emitted due to incomplete combustion. Important sources of $\mathrm{CO}$ include road transport, businesses, households, and industry. CO reacts with other pollutants producing ground-level ozone. $\mathrm{CO}$ can lead to heart disease and damage to the nervous system. It can also cause headache, dizziness, and fatigue.

- Ground-level (tropospheric) ozone is not directly emitted into the atmosphere. Instead, it forms in the atmosphere from a chain of chemical reactions following emissions of certain precursor gases: $\mathrm{NO}_{\mathrm{X}}$, carbon monoxide (CO), NMVOCs, and methane $\left(\mathrm{CH}_{4}\right)$. Elevated levels of ozone can cause respiratory health problems, including decreased lung function, aggravation of asthma, and other lung diseases. It can also lead to premature mortality. Ozone is also a greenhouse gas contributing to warming of the atmosphere."

The U.S. Environmental Protection Agency (which is a global environmental authority) has accepted these materials as the main air pollutants internationally $[7,8,9$, 10]. Similarly, they can be seen as the main air pollutants within academic studies on air pollution [11-18].

Such pollutants are also called "criteria pollutants," which is used internationally to describe air pollutants that have been regulated and are used as indicators of air quality [8]. Just as all over the world, these pollutants are taken into consideration as the major air pollutants by public authorities and the academicians in Turkey in order to prepare environmental reports and take measures against pollution [19].

\section{Stochastic Multi-Objective Acceptability Analysis 2}

Real life multi-criteria decision-making problems are usually based on decision makers' preferences. However, gathering such feedback might be very difficult or impossible in some cases because the decision makers might not be eager to reveal their preferences or the 
alternatives might have imprecise or uncertain data.

The original stochastic multi-objective acceptability analysis (SMAA) was developed in 1998 [20]. Stochastic multi-objective acceptability analysis is a multiplecriteria decision support technique for multiple decision makers based on exploring the weight space. Imprecise or uncertain input data can be represented as probability distributions. In SMAA, decision makers don't need to express their preferences explicitly or implicitly; instead, the technique analyzes what kind of valuations would make each alternative the preferred one. Imprecise or uncertain criteria values are represented by probability distributions from which the method computes confidence factors describing the reliability of the analysis.

As mentioned before, SMAA is developed for the conditions when the criteria values and/or weights and other parameters are imprecise or uncertain. Such imprecise or uncertain values are represented by stochastic variables, $\xi_{i j}$, with joint probability distribution and density function, $f(\xi)$, in space $X[21,22]$. The lack of knowledge about weights is represented by uniform weight distribution in weight set $\mathrm{W}[23]$.

The main purpose of SMAA is to provide decision support by means of descriptive measurements like multiple integrals. The original SMAA defines three main measurements: rank acceptability index, central weight vector, and confidence factor. The descriptive measurements are calculated using Monte Carlo simulation.

Rank acceptability index $\left(a_{i}\right)$ of an alternative defines the values that make it the most preferred one. Central weight vector $\left(w_{i}^{c}\right)$ for alternative $i$ is defined as the center of gravity of the polytope. Confidence factor $\left(p_{i}^{c}\right)$ measures whether the criteria evaluations are efficient in discriminating the effective alternatives.

Several SMAA variations are used to solve multicriteria decision-making problems of choosing, ranking, and classifying. SMAA-2, SMAA-3, SMAA-TRI, Ref-SMAA, SMAA-O, and SMAA-D can be given as examples.

SMAA-2 is an extended version of the original SMAA method. The original SMAA needs to be extended because the rank acceptability index does not rank the alternatives and instead classifies [23].

Several studies carried out by SMAA-2 can be seen in the MCDA literature. For example, Hokkanen performed a multi-criteria decision analysis application to be used in a competition to clean polluted soil in Helsinki. Nine firms competed across five criteria. The finalists were chosen by the help of SMAA-2 [24]. Lahdelma and Salminen used the method with the data of a former decision problem of constructing a new cargo harbor in Helsinki, which was solved by utilizing another decision-making method [23], and Kangas et al. have shown how SMAA-2 works on strategic forest planning [25].

The method was also employed within a phase of the study of Lahdelma et al. that seeks to develop a new method for handling dependent uncertainties in stochastic multi-criteria group decision-making problems.
The use of the method was demonstrated in the context of a strategic decision support model for an electricity retailer [26]. In a study performed in Morocco, different alternatives were evaluated using SMAA-2 to centralize multimodal cargo at a Moroccan airport hub in which significant uncertainty was present in both the criteria measurements and the preferences [27]. Aertsen et al. compared the performances of five modelling techniques for the prediction of a forest site index in two contrasting ecoregions in Belgium and Turkey [28]. SMAA-2 was found to be a suitable multi-criteria evaluation method to evaluate the performance of the modelling techniques. Tervonen et al. used SMAA-2 in their study for decision making in drug benefit-risk analysis [29]. The data of a former study were used to execute the results with the new method. Two antidepressant drugs and a placebo were used as alternatives in the analysis where efficacy, nausea, insomnia, and anxiety were used as criteria.

Another study was performed by Yang et al. in order to rank the performances of several decision-making units [30]. In the combinatorial study, SMAA-2 was used to rank the performances, which were measured using data envelopment analysis. Rahman et al. evaluated the off-grid technologies for a rural electrification problem by SMAA2 by aggregating 24 criteria values [31]. Pesola et al. used SMAA-2 to evaluate different implementation possibilities for remote monitoring systems for the municipal buildings of two medium-sized municipalities, Hollola and Nastola in southern Finland [32], and a solution was suggested after using SMAA-2 to resolve an important congestion and management problem in a government-owned port in Spain [33].

\section{Material and Methodology}

The implementation process consists of two stages. Within the first stage of the study the $81 \operatorname{cities}^{1}$ of Turkey are considered as the alternatives to be analyzed according to the aforementioned seven pollutant materials (criteria) for four seasons separately. The pollutant materials are considered the criteria of the study because those materials are widely accepted as the main air pollutants by both the public authorities and academic studies all over the world as mentioned in the second part of this study.

At the second stage, the same data are used with the same process to rank the 7 geographical regions ${ }^{2}$ in Turkey in terms of air pollution. We utilized JSMAA 1.03 software developed by Tervonen [34] for the analysis.

All cities are ranked according to air quality, but only the five most- and least-polluted are presented for the first stage in order to prevent information overload. The second stage presents all seven regions within the results.

The data are gathered from the monthly station reports on the Air Quality Monitoring Station website of the Ministry of Environment and Urbanization (113 separate stations for 81 cities) between 1/1/2014-31/12/2014.

\footnotetext{
${ }^{1}$ The list of the 81 cities is in Appendices.

${ }^{2}$ The regions are shown on a map in Appendices.
} 
Table 1. Ranking of the most- and least-polluted five provinces.

\begin{tabular}{|c|c|c|c|c|c|c|c|}
\hline \multicolumn{2}{|c|}{ Winter } & \multicolumn{2}{|c|}{ Spring } & \multicolumn{2}{|c|}{ Summer } & \multicolumn{2}{|c|}{ Autumn } \\
\hline M.P. & L.P. & M.P. & L.P. & M.P. & L.P. & M.P. & L.P. \\
\hline Bursa $^{x}$ & Adana $^{\mathrm{a}}$ & Düzce ${ }^{z}$ & Adana $^{a}$ & Siirt & İzmirc $^{c}$ & Şırnak ${ }^{y}$ & Adana $^{a}$ \\
\hline Şırnak ${ }^{y}$ & İstanbul & Sakarya & Rize $^{b}$ & İstanbul & Zonguldak & Kayseri & İzmirc \\
\hline Iğdır & Rize $^{b}$ & Hakkari & İzmir $^{c}$ & Karaman & Yozgat & K.Maraş & Van \\
\hline Düzce $^{z}$ & Eskişehir & Bursa $^{x}$ & Sivas & Kayseri & Van & Tekirdağ & Kocaeli \\
\hline Afyon $^{t}$ & İzmir $^{c}$ & İstanbul & Ankara & Bursa $^{x}$ & Kırıkkale & Afyon $^{t}$ & Kırşehir \\
\hline
\end{tabular}

M.P.: most polluted, L.P.: least polluted

\section{Results and Discussion}

After the analyses were done for both stages, the rankings of the cities and the regions were compiled into tables. Only the most polluted and the least polluted cities are tabulated along with the three main SMAA-2 measurements of rank acceptability index, central weight vector, and confidence factor (plus related graphical presentations that are shown just for the second stage due to the first stage having too many alternatives to be shown as graphics). Table 1 presents the ranking results of the first stage of the study.

According to Table 1, some remarkable points can be seen. First of all, several cities are seen on the lists consistently in most seasons. For example, regarding the "Most Polluted" cities list, Bursa appears in three of all four seasons. Similarly, on the "Least Polluted" cities list Adana appears at the top of the three seasons and İzmir can be seen on the same list for all seasons (even though it is not shown, Adana is in sixth place of the "Least Polluted" cities list for summer). All of the consistent cities are shown with superscripts on the table (Bursa: x, Şırnak: y, Düzce: z, Afyon: t; Adana: a, Rize: b, and İzmir: c).

A similar condition to the first stage of the study can be seen for the second stage on Table 2. The southeastern Anatolia region appears in first place in winter and autumn and in second place in spring and summer, whereas the Mediterranean region is found toward the end of the ranking for all seasons. The rank acceptability indexes, central weight vectors, and confidence factors of the regions for each season are shown in the matrix below.

Table 3 gives the rank acceptability indexes, central weight vectors, and confidence factors for each region. The results are presented graphically in Figs 1-4.

The results of the first stage indicate that some cities can be seen on the lists (both most and least polluted cities consistently as mentioned before). This shows the accuracy of the method and the analysis.

For the second stage, the results are again stable. The southeastern Anatolia and Marmara regions seem to be the most polluted two regions, while the Mediterranean is the least. Another confirmative point of the results is that Adana - the biggest city of the Mediterranean region - is the least-polluted city in the least-polluted region. In a similar manner, Bursa, Sakarya, Şırnak, and Hakkari - which are the most-polluted cities - belong to the most-polluted regions of Marmara and southeastern Anatolia.

A probable reason for the southeastern Anatolia region being the most polluted is the heavy usage of coal due to the lack of a natural gas infrastructure. Likewise, a reason for Marmara being one of the most-polluted regions might be the fact that it includes the largest industrial zones of the country. Being the most-populated region and having the most intense traffic increases the pollution of Marmara [35] (the population density map of Turkey is also presented in Appendices).

The results are highly compatible with the annual reports of the Ministry of Environment and Urbanization $[36,19]$. This also shows the accuracy of the analysis.

Table 2. Ranking of the regions in terms of air pollution.

\begin{tabular}{|c|c|c|c|}
\hline Winter & Spring & Summer & Autumn \\
\hline Southeastern Anatolia & Marmara & Marmara & Southeastern Anatolia \\
\hline Eastern Anatolia & Southeastern Anatolia & Southeastern Anatolia & Marmara \\
\hline Black Sea & Eastern Anatolia & Central Anatolia & Black Sea \\
\hline Aegean & Central Anatolia & Eastern Anatolia & Eastern Anatolia \\
\hline Marmara & Black Sea & Black Sea & Aegean \\
\hline Central Anatolia & Mediterranean & Aegean & Mediterranean \\
\hline Mediterranean & Aegean & Mediterranean & Anatolia \\
\hline
\end{tabular}


Table 3. SMAA-2 measurements of regions for four seasons.

\begin{tabular}{|c|c|c|c|c|c|c|c|c|c|c|c|c|c|c|c|}
\hline & \multicolumn{7}{|c|}{ Rank Acceptability Index } & \multirow{2}{*}{ CF } & \multicolumn{7}{|c|}{ Central Weight Vector } \\
\hline & R1 & $\mathrm{R} 2$ & $\mathrm{R} 3$ & $\mathrm{R} 4$ & R5 & R6 & R7 & & $\mathrm{PM}_{10}$ & $\mathrm{SO}_{2}$ & $\mathrm{CO}$ & NO & $\mathrm{NO}_{2}$ & $\mathrm{NO}_{\mathrm{x}}$ & $\mathrm{O}_{3}$ \\
\hline & \multicolumn{15}{|c|}{ WINTER } \\
\hline S.E. Anatolia & 0.2543 & 0.1843 & 0.1538 & 0.1374 & 0.1115 & 0.0894 & 0.0693 & 0.3142 & 0.1340 & 0.1728 & 0.1274 & 0.1419 & 0.1295 & 0.1475 & 0.1468 \\
\hline E. Anatolia & 0.1840 & 0.1790 & 0.1594 & 0.1397 & 0.1285 & 0.1147 & 0.0947 & 0.2091 & 0.1548 & 0.1405 & 0.1463 & 0.1490 & 0.1259 & 0.1449 & 0.1385 \\
\hline Black Sea & 0.1509 & 0.1518 & 0.1494 & 0.1379 & 0.1407 & 0.1452 & 0.1241 & 0.1638 & 0.1422 & 0.1209 & 0.1637 & 0.1401 & 0.1595 & 0.1376 & 0.1361 \\
\hline Aegean & 0.1177 & 0.1392 & 0.1485 & 0.1641 & 0.1574 & 0.1511 & 0.1220 & 0.1269 & 0.1732 & 0.1505 & 0.1213 & 0.1151 & 0.1705 & 0.1270 & 0.1423 \\
\hline Marmara & 0.0716 & 0.0895 & 0.1158 & 0.1350 & 0.1673 & 0.1821 & 0.2387 & 0.0713 & 0.1221 & 0.1267 & 0.1658 & 0.1469 & 0.1437 & 0.1863 & 0.1086 \\
\hline C. Anatolia & 0.0981 & 0.1089 & 0.1257 & 0.1344 & 0.1502 & 0.1713 & 0.2114 & 0.1033 & 0.1084 & 0.1242 & 0.1652 & 0.1686 & 0.1623 & 0.1474 & 0.1238 \\
\hline Mediterranean & 0.1234 & 0.1473 & 0.1474 & 0.1515 & 0.1444 & 0.1462 & 0.1398 & 0.1403 & 0.1608 & 0.1234 & 0.1203 & 0.1371 & 0.1392 & 0.1374 & 0.1818 \\
\hline Regions & \multicolumn{15}{|c|}{ SPRING } \\
\hline S.E. Anatolia & 0.2263 & 0.1967 & 0.1666 & 0.1387 & 0.1182 & 0.0922 & 0.0613 & 0.2587 & 0.1453 & 0.1449 & 0.1272 & 0.1448 & 0.1449 & 0.1385 & 0.1544 \\
\hline E. Anatolia & 0.1534 & 0.1733 & 0.1712 & 0.1596 & 0.1385 & 0.1199 & 0.0841 & 0.1748 & 0.1316 & 0.1584 & 0.1548 & 0.1479 & 0.1438 & 0.1236 & 0.1399 \\
\hline Black Sea & 0.0789 & 0.1035 & 0.1274 & 0.1465 & 0.1664 & 0.1861 & 0.1912 & 0.0756 & 0.1552 & 0.1108 & 0.1319 & 0.1755 & 0.1464 & 0.1434 & 0.1368 \\
\hline Aegean & 0.1348 & 0.1270 & 0.1219 & 0.1359 & 0.1473 & 0.1777 & 0.1554 & 0.1431 & 0.1674 & 0.1897 & 0.1255 & 0.1285 & 0.1301 & 0.1437 & 0.1151 \\
\hline Marmara & 0.2647 & 0.2069 & 0.1667 & 0.1289 & 0.1083 & 0.0771 & 0.0474 & 0.3243 & 0.1420 & 0.1316 & 0.1384 & 0.1384 & 0.1477 & 0.1682 & 0.1336 \\
\hline C. Anatolia & 0.0816 & 0.1260 & 0.1638 & 0.1889 & 0.1846 & 0.1567 & 0.0984 & 0.0803 & 0.1237 & 0.1166 & 0.1703 & 0.1459 & 0.1525 & 0.1507 & 0.1402 \\
\hline Mediterranean & 0.0603 & 0.0666 & 0.0824 & 0.1015 & 0.1367 & 0.1903 & 0.3622 & 0.0759 & 0.1336 & 0.1076 & 0.1796 & 0.1161 & 0.1350 & 0.1133 & 0.2147 \\
\hline Regions & \multicolumn{15}{|c|}{ SUMMER } \\
\hline S.E. Anatolia & 0.1888 & 0.1898 & 0.1844 & 0.1593 & 0.1328 & 0.0938 & 0.0511 & 0.2676 & 0.1989 & 0.1380 & 0.1281 & 0.1243 & 0.1355 & 0.1466 & 0.1286 \\
\hline E. Anatolia & 0.1266 & 0.1433 & 0.1578 & 0.1508 & 0.1511 & 0.1528 & 0.1176 & 0.1239 & 0.1446 & 0.1472 & 0.1402 & 0.1482 & 0.1432 & 0.1473 & 0.1294 \\
\hline Black Sea & 0.0616 & 0.0849 & 0.1078 & 0.1353 & 0.1679 & 0.2082 & 0.2343 & 0.0650 & 0.1120 & 0.1751 & 0.1759 & 0.1283 & 0.1425 & 0.1273 & 0.1389 \\
\hline Aegean & 0.1183 & 0.1219 & 0.1149 & 0.1324 & 0.1502 & 0.1629 & 0.1994 & 0.1142 & 0.1507 & 0.1516 & 0.1383 & 0.1252 & 0.1329 & 0.1355 & 0.1659 \\
\hline Marmara & 0.2125 & 0.1690 & 0.1534 & 0.1373 & 0.1229 & 0.1158 & 0.0891 & 0.2779 & 0.1220 & 0.1146 & 0.1593 & 0.1736 & 0.1426 & 0.1585 & 0.1294 \\
\hline C. Anatolia & 0.1321 & 0.1745 & 0.1770 & 0.1734 & 0.1536 & 0.1169 & 0.0725 & 0.1537 & 0.1338 & 0.1101 & 0.1386 & 0.1494 & 0.1733 & 0.1379 & 0.1569 \\
\hline Mediterranean & 0.1601 & 0.1166 & 0.1047 & 0.1115 & 0.1215 & 0.1496 & 0.2360 & 0.1820 & 0.1216 & 0.1869 & 0.1246 & 0.1286 & 0.1389 & 0.1408 & 0.1587 \\
\hline Regions & \multicolumn{15}{|c|}{ AUTUMN } \\
\hline S.E. Anatolia & 0.2166 & 0.1487 & 0.1398 & 0.1318 & 0.1219 & 0.1211 & 0.1201 & 0.2639 & 0.1627 & 0.1688 & 0.1328 & 0.1133 & 0.1520 & 0.1329 & 0.1375 \\
\hline E. Anatolia & 0.0945 & 0.1247 & 0.1540 & 0.1553 & 0.1639 & 0.1672 & 0.1404 & 0.1026 & 0.1522 & 0.1359 & 0.1419 & 0.1269 & 0.1396 & 0.1858 & 0.1177 \\
\hline Black Sea & 0.1335 & 0.1615 & 0.1606 & 0.1587 & 0.1556 & 0.1270 & 0.1031 & 0.1520 & 0.1416 & 0.1209 & 0.1653 & 0.1556 & 0.1479 & 0.1359 & 0.1328 \\
\hline Aegean & 0.1012 & 0.1136 & 0.1118 & 0.1349 & 0.1461 & 0.1737 & 0.2187 & 0.0936 & 0.1596 & 0.1694 & 0.1316 & 0.1435 & 0.1540 & 0.1085 & 0.1334 \\
\hline Marmara & 0.1608 & 0.1668 & 0.1593 & 0.1506 & 0.1391 & 0.1258 & 0.0976 & 0.1865 & 0.1391 & 0.1260 & 0.1440 & 0.1384 & 0.1314 & 0.1576 & 0.1635 \\
\hline C. Anatolia & 0.1737 & 0.1461 & 0.1363 & 0.1291 & 0.1307 & 0.1306 & 0.1535 & 0.1997 & 0.1247 & 0.1302 & 0.1445 & 0.1788 & 0.1373 & 0.1476 & 0.1369 \\
\hline Mediterranean & 0.1197 & 0.1386 & 0.1382 & 0.1396 & 0.1427 & 0.1546 & 0.1666 & 0.1289 & 0.1247 & 0.1393 & 0.1288 & 0.1421 & 0.1439 & 0.1521 & 0.1691 \\
\hline
\end{tabular}

R: rank, CF: confidence factor

\section{Conclusion}

The work presented here is a ranking study of places including cities in the first stage and regions in the second stage - in terms of the air quality that materialized with the quantities of the subject air pollutants in it. Evaluating the subject with an integrative approach makes this study unique despite the fact that the method used has already been utilized in several studies.

The main objective of this study is to show that such a ranking process done continuously by public authorities can be performed using the SMAA-2 method, and the 

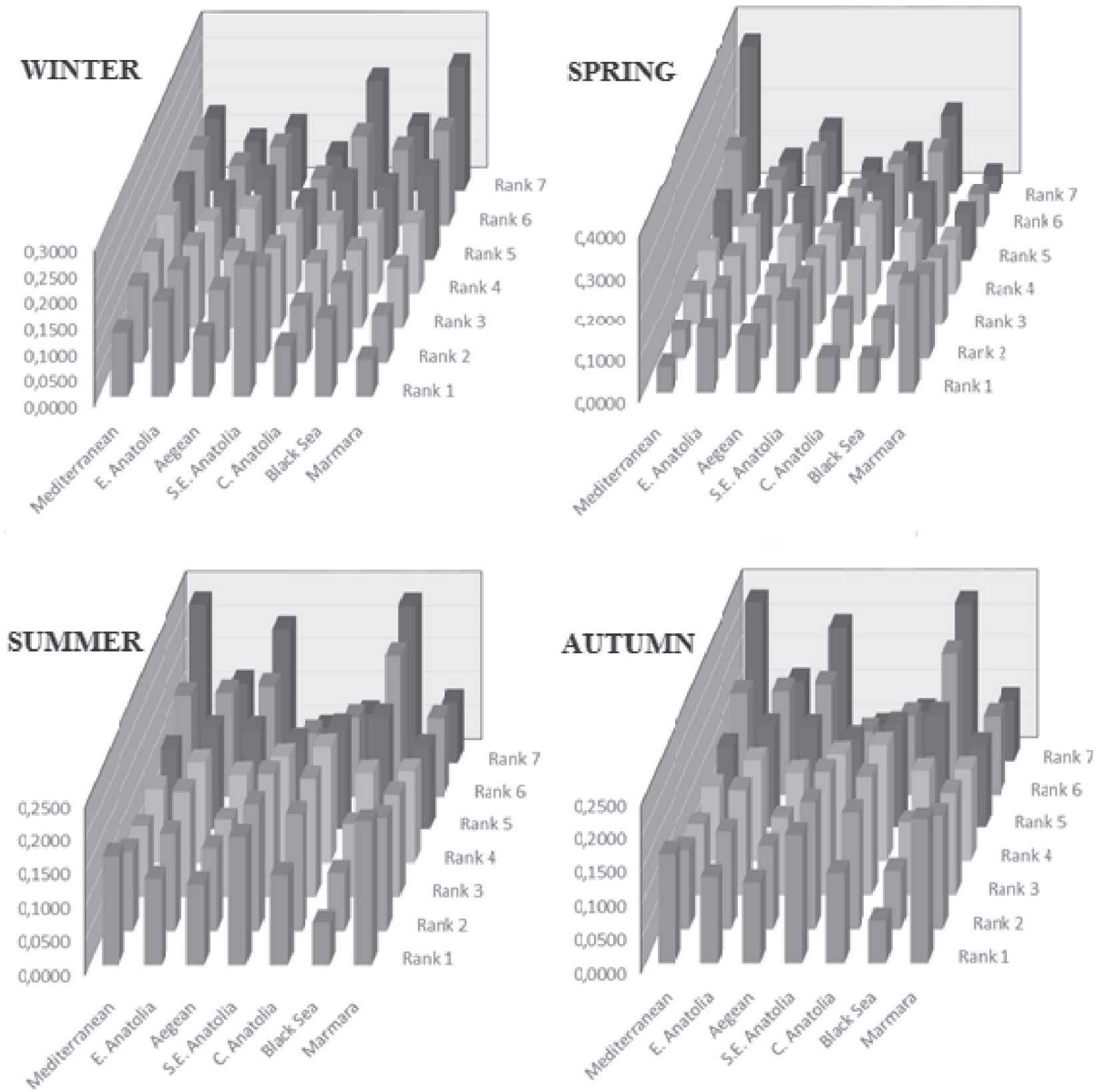

ERank1 ERank2 ERank3 ERank4 ERank5 ERank6 ERank7

Fig. 1. Joint Rank Acceptabilities.

Appendix A. List of Turkish cities.

\begin{tabular}{|c|c|c|c|c|c|c|c|c|}
\hline Adana & Balıkesir & Çorum & Giresun & Kastamonu & Maraş & Samsun & Uşak & Şırnak \\
\hline Adıyaman & Bilecik & Denizli & Gümüşhane & Kayseri & Mardin & Siirt & Van & Bartın \\
\hline Afyon & Bingöl & Diyarbakır & Hakkari & Kırklareli & Muğla & Sinop & Yozgat & Ardahan \\
\hline Ağrı & Bitlis & Edirne & Hatay & Kırşehir & Muş & Sivas & Zonguldak & Iğdır \\
\hline Amasya & Bolu & Elazı̆ & Isparta & Kocaeli & Nevşehir & Tekirdağ & Aksaray & Yalova \\
\hline Ankara & Burdur & Erzincan & İçel & Konya & Niğde & Tokat & Bayburt & Karabük \\
\hline Antalya & Bursa & Erzurum & İstanbul & Kütahya & Ordu & Trabzon & Karaman & Kilis \\
\hline Artvin & Çanakkale & Eskişehir & İzmir & Malatya & Rize & Tunceli & Batman & Osmaniye \\
\hline Aydın & Çankırı & Gaziantep & Kars & Manisa & Sakarya & Urfa & Kırıkkale & Düzce \\
\hline
\end{tabular}


Appendix B. Cites, regions, population density.
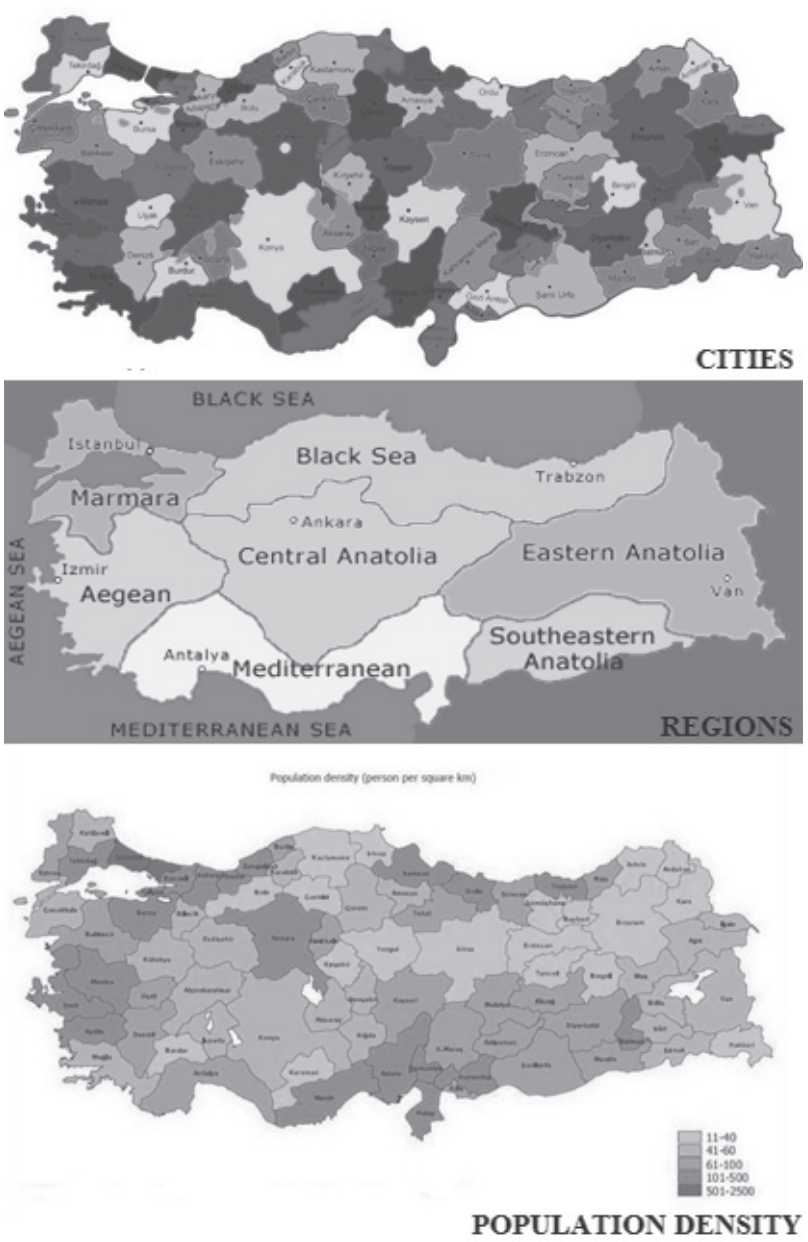

results can be seen in one vector using multiple criteria (instead of one) and needs no decision makers.

Further research could be done by conducting different ranking methods on the air-pollution issue. Similarly, other variations of SMAA-2 could be used for ranking, classifying, or choosing problems. Furthermore, hybrid models that are combined with SMAA-2 could attempt to analyze such data. The authors plan to carry out a combined data-mining study.

\section{References}

1. SILVA L. Environmental quality health index for cities. Habitat International. 45 (1), 29, 2015.

2. KUKREJA R. Conserve Energy Future. http://www. conserve-energy-future.com/15-current-environmentalproblems.php. 2015.

3. ENVIROPEDIA. Introduction to Air Quality. http://www. enviropedia.org.uk/Air_Quality/Air_Quality_Introduction. php. 2010.

4. DOBROT M., PETROVIC N., CIROVIC M., JEREMIC V. Measuring and Evaluating Air Pollution Per Inhabitant: A Statistical Approach. APCBEE Procedia. 5, 33, 2013.

5. SHENG N., TANG W. The first official city ranking by air quality in China - A review and analysis. Cities, 2015 - [In Press].
6. EUROPEAN ENVIRONMENT AGENCY. Air pollution fact sheet 2013. European Environment Agency, Copenhagen, 2014.

7. U.S. ENVIRONMENTAL PROTECTION AGENCY. What Are the Six Common Air Pollutants? http://www3.epa.gov/ airquality/urbanair/, 2010.

8. AUSTRALIAN GOVERNMENT DEPARTMENT OF THE ENVIRONMENT. Air Pollutants. http://www.environment. gov.au/protection/air-quality/air-pollutants\#criteria 2015.

9. U.K. DEPARTMENT FOR ENVIRONMENT, FOOD \& RURAL AFFAIRS. Guide to UK Air Pollution Information Resources. U.K. Department for Environment, Food \& Rural Affairs, London, 2014.

10. U.S. CENTERS FOR DISEASE CONTROL AND PREVENTION. Air Pollutants. http://www.cdc.gov/air/ pollutants.htm. 2014.

11. YOO J. M., LEE Y.R., KIM D, JEONG M.J., STOCKWELL W., KUNDU P., OH S.M., SHIN D.B., LEE S.J. New indices for wet scavenging of air pollutants $(\mathrm{O} 3, \mathrm{CO}, \mathrm{NO} 2, \mathrm{SO} 2$, and PM10) by summertime rain. Atmospheric Environment. 82, 226, 2014.

12. ITO K, THURSTON G., SILVERMAN R. Characterization of PM2.5, gaseous pollutants, and meteorological interactions in the context of time-series health effects models. Journal of Exposure Science and Environmental Epidemiology, 17 (2), 45, 2007.

13. ELMINIR H. Dependence of urban air pollutants on meteorology. Science of the Total Environment. 350 (1-3), 225, 2005.

14. KALANTZI E., MAKRIS D., DUQUENNE M.N., KAKLAMANI S., STAPOUNTZIS H., GOURGOULIANIS K. Air pollutants and morbidity of cardiopulmonary diseases in a semi-urban Greek peninsula. Atmospheric Environment. 45 (39), 7121, 2011.

15. TAŞDEMIR Y., CINDORUK S., ESEN F. Monitoring of criteria air pollutants in Bursa, Turkey. Environmental Monitoring and Assessment. 110 (1-3), 227, 2005.

16. LEI Y., ZHANG Q., NIELSEN C., HE K. An inventory of primary air pollutants and $\mathrm{CO} 2$ emissions from cement production in China, 1990-2020. Atmospheric Environment. 45 (1), 147, 2011.

17. MERAZ M., RODRIGUEZ E., FEMAT R., ECHEVERRIA J., ALVAREZ-RAMIREZ J. Statistical persistence of air pollutants (O3,SO2,NO2 and PM10) in Mexico City. Physica A: Statistical Mechanics and its Applications. 427, 202, 2015.

18. ZHENG X.Y., DING H., JIANG L.N., CHEN S.W., ZHENG J.P., QUI M., ZHUO Y.X., CHEN Q., GUAN W.J. Association between air pollutants and asthma emergency room visits and hospital admissions in time series studies: A systematic review and meta-analysis. Plos One. 10 (9), 1, 2015.

19. MINISTRY OF ENVIRONMENT AND URBANIZATION. Air Quality Report of 2014. Ministry of Environment and Urbanization - Directorate General of Environmental Impact, Assessment, Permit and Inspection, Ankara, 2015.

20. LAHDELMA R., HOKKANEN J., SALMINEN P. SMAAStochastic multiobjective acceptability analysis. European Journal of Operational Research. 106 (1), 137, 1998.

21. OKUL D. SMAA and TOPSIS integration for stochastic multi-criteria decision making and an application to machine gun selection problem. [Unpublished Doctoral Dissertation] Ankara: Turkish Military Academy Defence Science Institute Department of Operations Research, 2012.

22. OKUL D., GENCER C., AYDOĞAN KIZILKAYA E. A Method Based on SMAA-Topsis for Stochastic Multi- 
Criteria Decision Making and a Real-World Application. International Journal of Information Technology \& Decision Making. 13 (5), 957, 2014.

23. LAHDELMA R., SALMINEN P. SMAA-2: Stochastic multi-criteria acceptability analysis for group decision making. Operations Research, 49 (3), 444, 2001.

24. HOKKANEN J., LAHDELMA R., SALMINEN P. Multicriteria decision support in a technology competition for cleaning polluted soil in Helsinki. Journal of Environmental Management. 60 (4), 339, 2000.

25. KANGAS A., KANGAS J., LAHDELMA R., SALMINEN P. Using SMAA-2 method with dependent uncertainties for strategic forest planning. Forest Policy and Economics. 9 (2), 113, 2006

26. LAHDELMA R., MAKKONEN S., SALMINEN P. Multivariate Gaussian criteria in SMAA. European Journal of Operational Research. 170 (3), 957, 2006.

27. MENOU A., BENALLOU A., LAHDELMA R., SALMINEN P. Decision support for centralizing cargo at a Moroccan airport hub using stochastic multicriteria acceptability analysis. European Journal of Operational Research. 204 (3), 621, 2010.

28. AERTSEN W., KINT V., VAN ORSHOVEN J., MUYS B. Evaluation of modelling techniques for forest site productivity prediction in contrasting ecoregions using stochastic multicriteria acceptability analysis (SMAA). Environmental Modelling \& Software. 26 (7), 929, 2011.

29. TERVONEN T., VAN VALKENHOF G., BUSKENS E.,
HILlEGE H., POSTMUS D. A stochastic multicriteria model for evidence-based decision making in drug benefitrisk analysis. Statistics in Medicine. 30 (12), 1419, 2011.

30. YANG F., ANG S., XIA Q., YANG C. Ranking DMUs by using interval DEA cross efficiency matrix with acceptability analysis. European Journal of Operational Research. 223 (2), 483, 2012.

31. RAHMAN M., PAATERO J., LAHDELMA R. Evaluation of choices for sustainable rural electrification in developing countries: A multicriteria approach. Energy Policy. 59, 589, 2013.

32. PESOLA A., SERKKOLA A., LAHDELMA R., SALMINEN P. Multicriteria evaluation of alternatives for remote monitoring. Energy and Buildings. 72, 229, 2014.

33. GACIA-MORALES R., BAQUERIZO A., LOSADA M. A. Port management and multiple-criteria decision making under uncertainty. Ocean Engineering. 104, 31, 2015.

34. TERVONEN T. JSMAA: open source software for SMAA computations. International Journal of Systems Science. 45 (1), 69, 2014

35. EUROPEAN ENVIRONMENT AGENCY. Population density in Turkey. http://www.eea.europa.eu/soer/countries/ tr/country-introduction-turkey/2.jpg/view .2015.

36. T24. Çevre Raporu: İstanbul ve 32 ilde su, Ankara ile birlikte 27 ilin havas1 kirli. 28 February 2015. [In Turkish]. http:// t24.com.tr/haber/cevre-raporu-istanbul-ve-32-ilde-suankara-ile-birlikte-27-ilin-havasi-kirli,288878. 